\title{
Chitosan microspheres/sodium alginate hybrid beads: an efficient green adsorbent for heavy metals removal from aqueous solutions
}

\author{
El-houssaine Ablouh ${ }^{1,2^{*}}$, Zouhair Hanani ${ }^{1}$, Nadia Eladlani ${ }^{2}$, Mohammed Rhazi ${ }^{2}$ and Moha Taourirte ${ }^{1}$
}

\begin{abstract}
Heavy metal toxicity has demonstrated to be a crucial issue for environment and human health. There has been an increasing ecological and global public health concern related with environmental contamination by these metals. For these reasons, a considerable attention has been paid to design efficient materials for heavy metal removal. This article offers a solution to develop a green adsorbent based on Chitosan Microspheres/Sodium Alginate hybrid beads (CSM/ SA) for metal ion elimination from aqueous solutions. The efficiency of this eco-friendly material was divulged using kinetic study for $\mathrm{Cr}(\mathrm{VI})$ and $\mathrm{Pb}(\mathrm{II})$ removal. Properties of the obtained hybrid beads were improved by correlation between original chitosan microspheres and sodium alginate. Moreover, at different metal concentration, pH solution and contact time, the beads were evaluated in discharged batch operations from $\mathrm{Pb}(\mathrm{II})$ and $\mathrm{Cr}(\mathrm{VI})$. The maximum adsorption capacity was $180 \mathrm{mg} \mathrm{g}^{-1}$ for $\mathrm{Pb}(\mathrm{II})$ and $16 \mathrm{mg} \mathrm{g}^{-1}$ for $\mathrm{Cr}(\mathrm{VI})$. The adsorption kinetics were evaluated using pseudo-first and pseudo-second rate models. Adsorption isotherms were simulated by Langmuir and Freundlich models. This study indicates that the CSM/SA hybrid beads could be developed into a very sustainable technology for highly effective elimination of metal ions from wastewater.
\end{abstract}

Keywords: Chitosan microspheres, Sodium alginate, Green adsorbent, Heavy metals, Toxicity

\section{Introduction}

Contamination of water with toxic compounds, such as heavy metals and dyes, even at low concentration, remains a serious environmental issue due to their dangerous effects on human health $[1,2]$. The use of heavy metals arises in various industries such as metallurgy, chemical industry, papermaking, electroplating, steel fabrication, anodizing baths, leather tanning, cement preservation, canning industries and textile $[3,4]$. These highly toxic metal ions including lead and chromium exert enormous effects on environment $[5,6]$. To overcome this serious problem, considerable attention has been paid to develop new approaches to remove toxic metal ions from polluted environmental matrices, e.g., physicochemical techniques namely precipitation, ion-exchange, electrochemistry, membrane ultrafiltration

\footnotetext{
* Correspondence: Ihoussainiblah@gmail.com

'Department of Chemistry, Cadi Ayyad University, 40000 Marrakesh, Morocco ${ }^{2}$ Higher Normal School, Cadi Ayyad University, 40000 Marrakesh, Morocco
}

and chemical adsorption [7]. Among them, adsorption process is more preferable because of its ease and the use of small amounts of chemical additives as well as the possibility of reusing adsorbent materials. Selectivity is the effective property for heavy metal removal alongside to their low-cost. For these reasons, several attempts have been made to develop efficient and economic eco-friendly materials originated from natural sources, which are called "green adsorbents" [8].

Natural polymers are frequently used as adsorbents owing to their reproducibility, biodegradability, biocompatibility, renewability and very low production cost compared to synthetic polymers [9]. In particular, chitosan has been demonstrated to be an appropriate natural compound for metallic ion adsorption [10]. Beside the abundance of this natural biopolymer, chitosan has many functional groups, which enable its binding to various metallic ions through electrostatic attraction or hydrogen bonding [11]. Meanwhile, sodium alginate is a

(c) The Author(s). 2019 Open Access This article is distributed under the terms of the Creative Commons Attribution 4.0 International License (http://creativecommons.org/licenses/by/4.0/), which permits unrestricted use, distribution, and 
binary heteropolymer, containing alternating blocks of linearly organized 1-4 linked $\alpha$-L-guluronic and $\beta$-D-mannuronic acid [12]. The presence of carboxylic and hydroxyl groups in alginate can bind metallic ions [13]. However, sodium alginate is soluble in water, which generates a difficult separation from aqueous solution. To overcome the solubility drawback of sodium alginate, sodium was substituted by calcium [14].

The conception of chitosan microspheres and their dispersion in alginate matrix to produce millimeter-sized hybrid beads is a viable alternative adsorbent. The new functional groups are combined to increase the adsorption sites and metal adsorption selectivity. Many studies have concentrated on the use of hybrid beads by mixing two or more components with different physical or chemical properties for the removal of heavy metals [15]. The stabilization of bead-based polymers was carried out via cross-linking or grafting processes [16].

The aim of this study is to shed light into an effective strategy to eliminate heavy metal ions like $\mathrm{Pb}(\mathrm{II})$ and $\mathrm{Cr}(\mathrm{VI})$ using a novel eco-friendly adsorbent based on chitosan microspheres (CSM) and sodium alginate (SA) and calcium as a cross linking agent. After physico-chemical characterizations of this green adsorbent (CSM/SA), an intensive work was made to evaluate its efficiency through $\mathrm{Pb}(\mathrm{II})$ and $\mathrm{Cr}(\mathrm{VI})$ ion removal from aqueous system. Then, the effects of contact time, $\mathrm{pH}$, temperature and initial concentration of metal ions on the adsorption capacity of CSM/SA hybrid beads were studied. Finally, kinetics equilibrium and isotherms studies were carried out to explain the adsorption process of $\mathrm{Pb}(\mathrm{II})$ and $\mathrm{Cr}(\mathrm{VI})$ by CSM/SA hybrid beads.

\section{Materials and methods Materials}

Sodium alginate with average molecular weight $250-360$ $\mathrm{kDa}$ and viscosity $5-40 \mathrm{cP}$ was purchased from Sigma-Aldrich. Chitosan was prepared according to our previous study [17]. Lead chloride powder (98\%), 37\% hydrochloric acid, sodium hydroxide, acetic acid and calcium chloride dehydrate were purchased from Analar Normapur. $\mathrm{Cr}(\mathrm{VI})$ stock solution was prepared from potassium salts of dichromate $\left(\mathrm{K}_{2} \mathrm{Cr}_{2} \mathrm{O}_{7}\right)$. All reagents were of analytical grade and were used as received without further purification.

\section{Preparation of CSM}

The CSM was prepared according to the procedure used by Berthold and his coworkers [18], with some modifications. Briefly, chitosan solution was obtained by dissolving chitosan in 1 vol\% acetic acid solution. Then, sodium sulfate solution $25 \mathrm{wt} \%$ was slowly added $\left(4 \mathrm{~mL} \mathrm{~h}^{-1}\right)$ to chitosan solution at $300 \mathrm{rpm}$. Finally, after $3 \mathrm{~h}$ of magnetic stirring, chitosan microspheres were collected by centrifugation at $4000 \mathrm{rpm}$ for $20 \mathrm{~min}$, and washed with deionized water.

\section{Preparation of CSM/SA hybrid beads}

The CSM/SA hybrid beads were prepared by mixing chitosan microspheres and sodium alginate solution. To begin with, $1 \mathrm{~g}$ of sodium alginate was dissolved in 100 $\mathrm{mL}$ of deionized water with a constant stirring. Then, the previous dispersion of chitosan microspheres was dropped into a homogeneous alginate solution under magnetic stirring ( $400 \mathrm{rpm}$ ) for $4 \mathrm{~h}$ at room temperature. By mixing above prepared solutions, an emulsion was formed. The obtained emulsion was added drop wise to $0.2 \mathrm{M}$ calcium chloride solution, under continuous magnetic stirring to complete the cross-linking process. The formed CSM/SA beads were washed three times with deionized water and then dried.

\section{Characterization of CSM/SA beads}

The functional groups of CSM/SA hybrid beads were analyzed using Fourier Transform Infrared Spectroscopy (FTIR, Jasco-6030) operated at $4 \mathrm{~cm}^{-1}$ over a range of $4000-400 \mathrm{~cm}^{-1}$ by attenuated total reflection (ATR). Surface morphology of CSM/SA hybrid beads was obtained using Scanning Electron Microscopy (SEM, Tescan, Vega3), with an accelerating voltage of $20 \mathrm{kV}$. Energy dispersive X-ray (EDX) analyzer was employed to divulgate the different elements presenting in CSM/SA before and after adsorption. The thermal properties of CSM/SA beads were also studied using thermogravimetry (TGA)-differential thermal analysis (DTA) (Labsys Evo TGA/STA-EGA) and differential scanning calorimetry (DSC, Perkin Elmer). Both analytical techniques were carried out with a heating rate of $10{ }^{\circ} \mathrm{C} \mathrm{min}-1$, under nitrogen flow. The $\mathrm{pH}$ drift method was used for the determination of the point of zero charge (PZC) of CSM/SA beads [15]. $50 \mathrm{~mL}$ of $\mathrm{NaCl}(0.01 \mathrm{M})$ solution was taken in a series of fives Erlenmeyer flasks. The range of initial $\mathrm{pH}$ values was adjusted between 2 and 10 by adding $0.1 \mathrm{M} \mathrm{NaOH}$ and $0.1 \mathrm{M} \mathrm{HCl}$. Then, $0.01 \mathrm{~g}$ of correctly weighed CSM/SA beads was added to each flask shaking at $300 \mathrm{rpm}$ for $24 \mathrm{~h}$ then the final $\mathrm{pH}$ was noted. BET surface area of CSM/SA adsorbent was measured using surface area analyzer (Micrometritics, ASAP 2010) at $77 \mathrm{~K}$.

\section{Batch experiments of heavy metals ion adsorption}

Adsorption of $\mathrm{Cr}(\mathrm{VI})$ and $\mathrm{Pb}(\mathrm{II})$ was carried out using the bottle point methods. Metallic ion solutions were prepared by dissolving $\mathrm{PbCl}_{2}$ and $\mathrm{K}_{2} \mathrm{Cr}_{2} \mathrm{O}_{7}$ in distilled water. $0.1 \mathrm{M}$ of $\mathrm{NaOH}$ and $\mathrm{HCl}$ was used to regulate the solution $\mathrm{pH}$. The concentrations of metal solutions were measured using an atomic absorption spectrophotometer at 217 and $370 \mathrm{~nm}$ for $\mathrm{Pb}(\mathrm{II})$ and $\mathrm{Cr}(\mathrm{VI})$, 
respectively. The effect of $\mathrm{pH}$ solution on adsorption process was studied in the $\mathrm{pH}$ range of 2-10 for $\mathrm{Cr}(\mathrm{VI})$ and 2-6 for $\mathrm{Pb}(\mathrm{II})$. The effects of solution temperature $\left(20-55^{\circ} \mathrm{C}\right)$, adsorbent dose $(5-35 \mathrm{mg})$, contact time (0-260 min) and metallic ion concentration $\left(25-300 \mathrm{mg} \mathrm{L}^{-1}\right)$ on removal efficiency were investigated in a batch system.

The adsorption capacity of metallic ions, $\mathrm{q}_{\mathrm{e}}\left(\mathrm{mg} \mathrm{g}^{-1}\right)$, was calculated according to the following Eq. (1).

$$
q_{e}=\frac{\left(C_{i}-C_{e}\right)}{W} \times V
$$

The removal efficiency (\%) of metallic ions can be expressed using the Eq. (2).

$$
\text { \%adsorption }=\frac{\left(C_{i}-C_{e}\right)}{C_{i}} \times 100
$$

The adsorption capacity of metallic ions $\mathrm{q}_{\mathrm{t}}\left(\mathrm{mg} \mathrm{g}^{-1}\right)$ at time "t" can be obtained by Eq. (3).

$$
q_{t}=\frac{\left(C_{i}-C_{t}\right)}{W} \times V
$$

Where $C_{i}, C_{e}$ and $C_{t}$ are respectively the initial, equilibrium and any time of metallic concentration $\left(\mathrm{mg} \mathrm{L}^{-1}\right)$. $\mathrm{V}$ is the volume of metallic solution (L) and $\mathrm{W}$ is the mass of CSM/SA (g).

\section{Results and discussion \\ Characterization studies}

The TGA-DTA analysis of CSM/SA adsorbent are illustrated in Fig. 1a. It displays four stages thermal degradation of the hybrid beads. The first step was from 25 to $240{ }^{\circ} \mathrm{C}$ (weight loss 9.7\%) corresponding to the entrapped water molecules in the network [19]. The second and third weight losses observed between 240 and $370{ }^{\circ} \mathrm{C}$ is due to biopolymers decomposition. The last stage of the thermal degradation of CSM/SA beads between 370 and $525^{\circ} \mathrm{C}$ was attributed to the formation of $\mathrm{Na}_{2} \mathrm{CO}_{3}$ with a weight loss of $17.1 \%$ [20-22]. It is worth noting that the DTA features are consistent with the TGA results. The first DTA peak (endothermic) indicates the energy required to evaporate water physically adsorbed in CSM/SA beads. The two exothermic peaks at 248 and $347^{\circ} \mathrm{C}$ were attributed to the energy released from burning organic products. However, the exothermic peak at $447^{\circ} \mathrm{C}$ corresponds to the formation of $\mathrm{Na}_{2} \mathrm{CO}_{3}$.

The DSC curve of CSM/SA beads was recorded from 0 to $400{ }^{\circ} \mathrm{C}$ (Fig. 1b). An endothermic peak at $64{ }^{\circ} \mathrm{C}$, corresponds to water evaporation, this is consistent with the results obtained by TGA. Three exothermic peaks can be observed, at 277,349 and $373{ }^{\circ} \mathrm{C}$ due to thermal degradation of organic materials of the adsorbent.

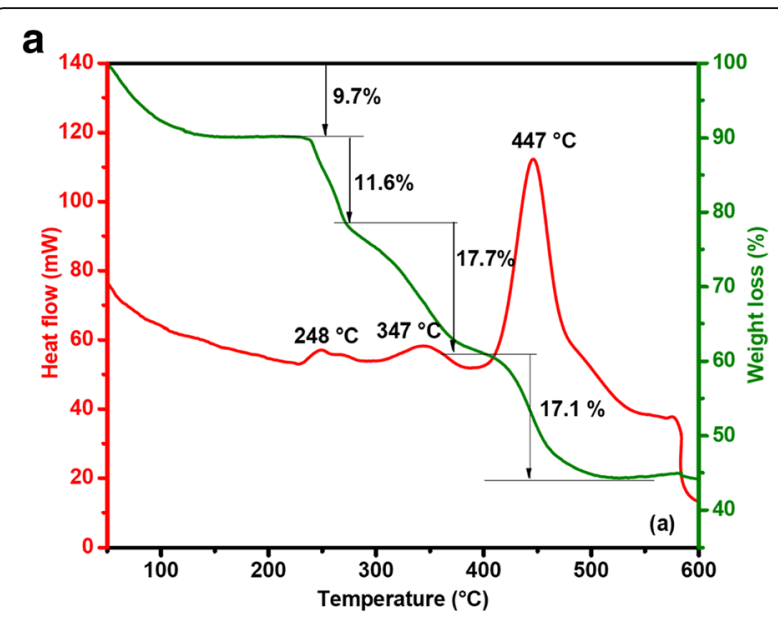

b

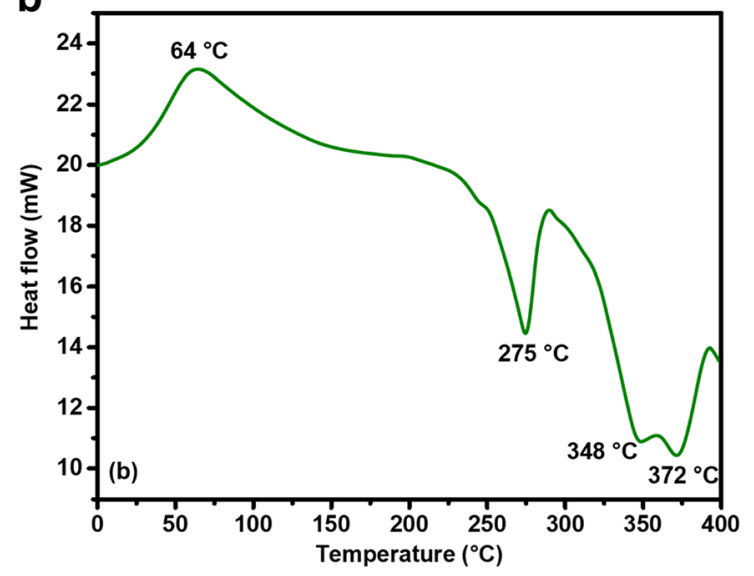

Fig. 1 Thermal behavior of CSM/SA hybrid beads: a DTA/TGA thermograms and $\mathbf{b}$ DSC curve

Figure 2 shows ATR-FTIR results of CSM/SA hybrid beads before and after adsorption process. The band around $1620 \mathrm{~cm}^{-1}$, attributed to amide I vibration of chitosan microspheres cannot be observed [23]. This can be explained by the overlapping with stronger asymmetric vibration band of $\mathrm{COO}^{-}$belonging to alginate [7] The broad peak observed at $3250 \mathrm{~cm}^{-1}$ was correspond to the intermolecular hydrogen bonded $\mathrm{O}-\mathrm{H}$ stretching and stretching vibration $\mathrm{N}-\mathrm{H}$ [24]. The peaks obtained at 1312,1019 and $1012 \mathrm{~cm}^{-1}$ indicate the presence of $\mathrm{OH}$ in-plane bending, $\mathrm{C}-\mathrm{O}$ stretching and $\mathrm{C}-\mathrm{O}-\mathrm{C}$ bending, respectively [25]. The absence of the peak corresponding to the amine group $\left(1160 \mathrm{~cm}^{-1}\right)$ in the CSM/ SA bead spectrum confirms the formation of electrostatic interactions between positively charged amino groups $\left(-\mathrm{NH}_{3}{ }^{+}\right)$of chitosan and negatively charged carboxylic units $\left(-\mathrm{COO}^{-}\right)$of alginate [26]. As illustrated in Fig. 2, after $\mathrm{Cr}(\mathrm{VI})$ adsorption, it was observed that the stretching vibration peak of $-\mathrm{OH}$ or $\mathrm{NH}_{2}$ at around $3250 \mathrm{~cm}^{-1}$ shifted to $3245 \mathrm{~cm}^{-1}$. This indicates the formation of hydrogen bonds between the hydrogen atoms 


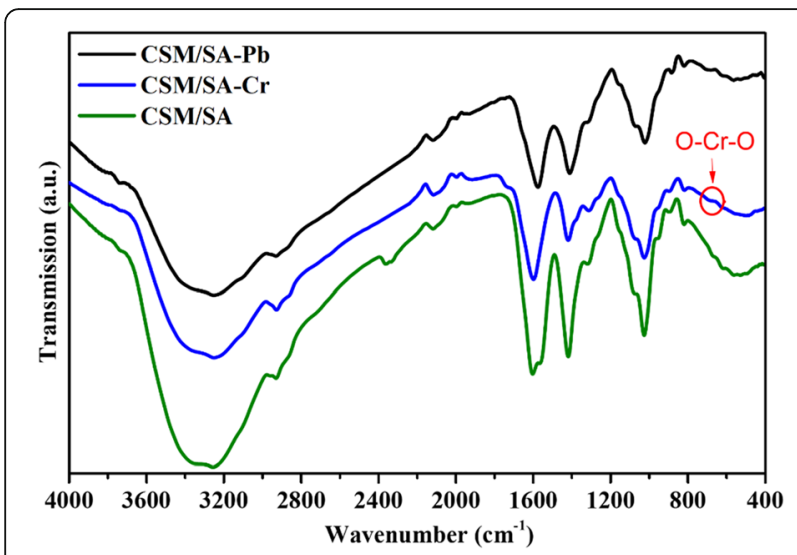

Fig. 2 ATR-FTIR spectra of CSM/SA hybrid beads, (CSM/SA-Pb) CSM/ CA hybrid beads loaded $\mathrm{Pb}(\mathrm{II})$ and (CSM/SA-Cr) CSM/CA hybrid beads loaded $\mathrm{Cr}(\mathrm{VI})$

on $\mathrm{NH}_{2}$ groups and $\mathrm{O}$ atoms of oxyanion species of $\mathrm{Cr}(\mathrm{VI})$ [27]. Meanwhile, the slight shifting characteristic of the peak corresponding to $\mathrm{COO}$ bond from 1600 to $1590 \mathrm{~cm}^{-1}$ could be indicative of the interactions between $\mathrm{COO}$ groups and $\mathrm{Cr}(\mathrm{VI})$. These displacements explain the electrostatic interaction between $\mathrm{Cr}(\mathrm{VI})$ and $\mathrm{OH}$, $\mathrm{COO}, \mathrm{NH}_{3}{ }^{+}$groups. In addition, a new peak appears at $682 \mathrm{~cm}^{-1}$ (CSM/SA-Cr) which could be mostly due to $\mathrm{O}-\mathrm{Cr}-\mathrm{O}$ band belonging to $\mathrm{Cr}$ species [28] .

After adsorption of $\mathrm{Pb}(\mathrm{II})$, a shifting of some bands was observed. The stretching vibration of $\mathrm{O}-\mathrm{H}$ band was significantly shifted from 3250 to $3261 \mathrm{~cm}^{-1}$, and the characteristic peak of the $\mathrm{COO}$ bond showed a strong shift from 1600 to $1569 \mathrm{~cm}^{-1}$. These peaks displacement could be due to the coordination effect of the $\mathrm{O}$ atom and $\mathrm{Pb}(\mathrm{II})$ ions, which indicates the ion exchange between $\mathrm{Pb}^{2+}$ and $\mathrm{Ca}^{2+}$ on the interlayer surface of CSM/ SA [29]. Furthermore, no new obvious absorption band was observed after $\mathrm{Pb}$ (II) adsorption.

Using the SEM microscopy, elemental mapping was performed and EDX spectra were collected for CSM/SA sample before and after adsorption of both ions. The results are represented in Figs. 3 and 4. SEM was used to provide an idea on the homogeneity and the microstructure of CSM/SA hybrid beads. Figure 3a exposes that a large number of granular microspheres with a uniform size were dispersed on the surface of alginate. Probably, this may be due to the presence of carboxyl groups of alginate $\left(\mathrm{COO}^{-}\right)$which can interact with amino groups $\left(\mathrm{NH}_{3}{ }^{+}\right)$of chitosan microspheres [14]. On the other hand, the morphological characteristics of these hybrid beads will be mostly due to the original alginate microstructure, with a slight increase in the specific interfacial area. EDX analysis of hybrid beads confirms the existence of small amount of nitrogen (1.5\%) observed on the surface, while the major percentages 38.3, 36.4 and 23.7\% correspond to C, $\mathrm{Ca}$ and $\mathrm{O}$, respectively (Fig. 4).

The surface area is an important parameter in adsorption study. For this purpose, BET method was applied to evaluate the surface area of CSM/SA adsorbent and found to be $76 \mathrm{~m}^{2} \mathrm{~g}^{-1}$. This result indicates that the prepared CSM/SA have a relatively high surface area compared to some adsorbent based chitosan and alginate [30].

In order to have more insights on the chemical composition and the spatial distribution of elements on the surface of CSM/SA adsorbent, the elemental mapping was employed using EDX. The results are outlined in Fig. 4. A homogeneous distribution of the cited elements was approved on CSM/SA hybrid beads before and after metals loaded. Carbon and oxygen corresponding micrographs for the hybrid beads before and after adsorption indicate the distribution of the functional groups on the surface. After adsorption process, Fig. 4c illustrates that the adsorption of lead ions onto CSM/SA induces many changes in the adsorbent surface. Similarly, for chromium ion elimination, SEM micrograph shows glossy and bright microspheres of chitosan on the uniform surface, which indicates a low interaction between $\mathrm{Cr}(\mathrm{VI})$ and the adsorbent (Fig. 4b).

From the typical EDX graphs and elemental mapping, a new peak around $2.5 \mathrm{keV}$ appears after adsorption process with dense distribution at CSM/SA surface, was attributed to $\mathrm{Pb}$ element (31.6\%). Meanwhile, $\mathrm{Ca}$ peak disappears in the EDX spectrum after
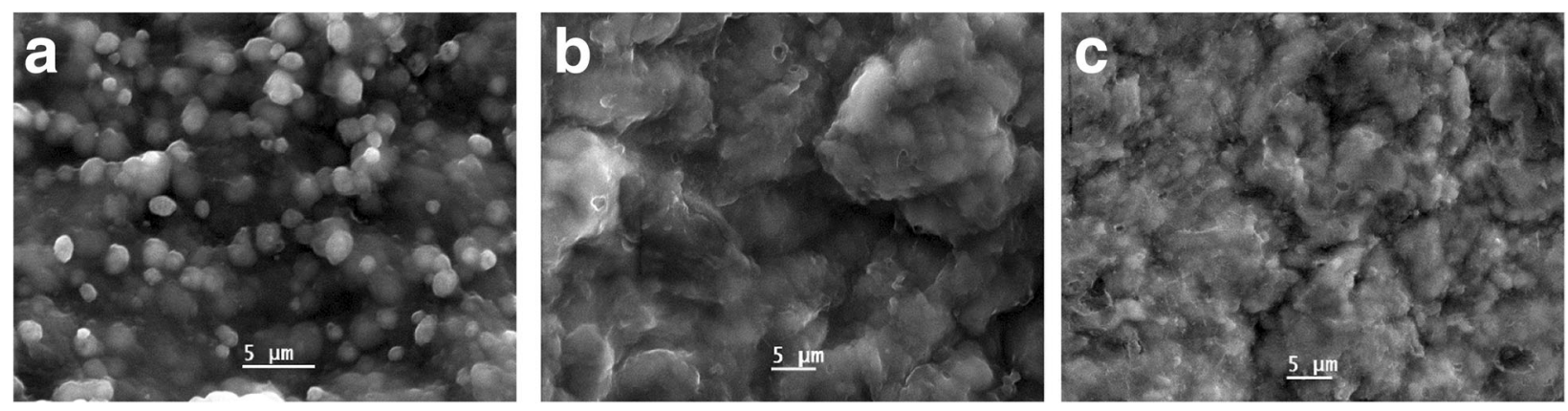

Fig. 3 SEM micrographs of the prepared CSM/SA hybrid beads: a before metal adsorption, b After Cr(VI) loading, c After Pb(II) loading 

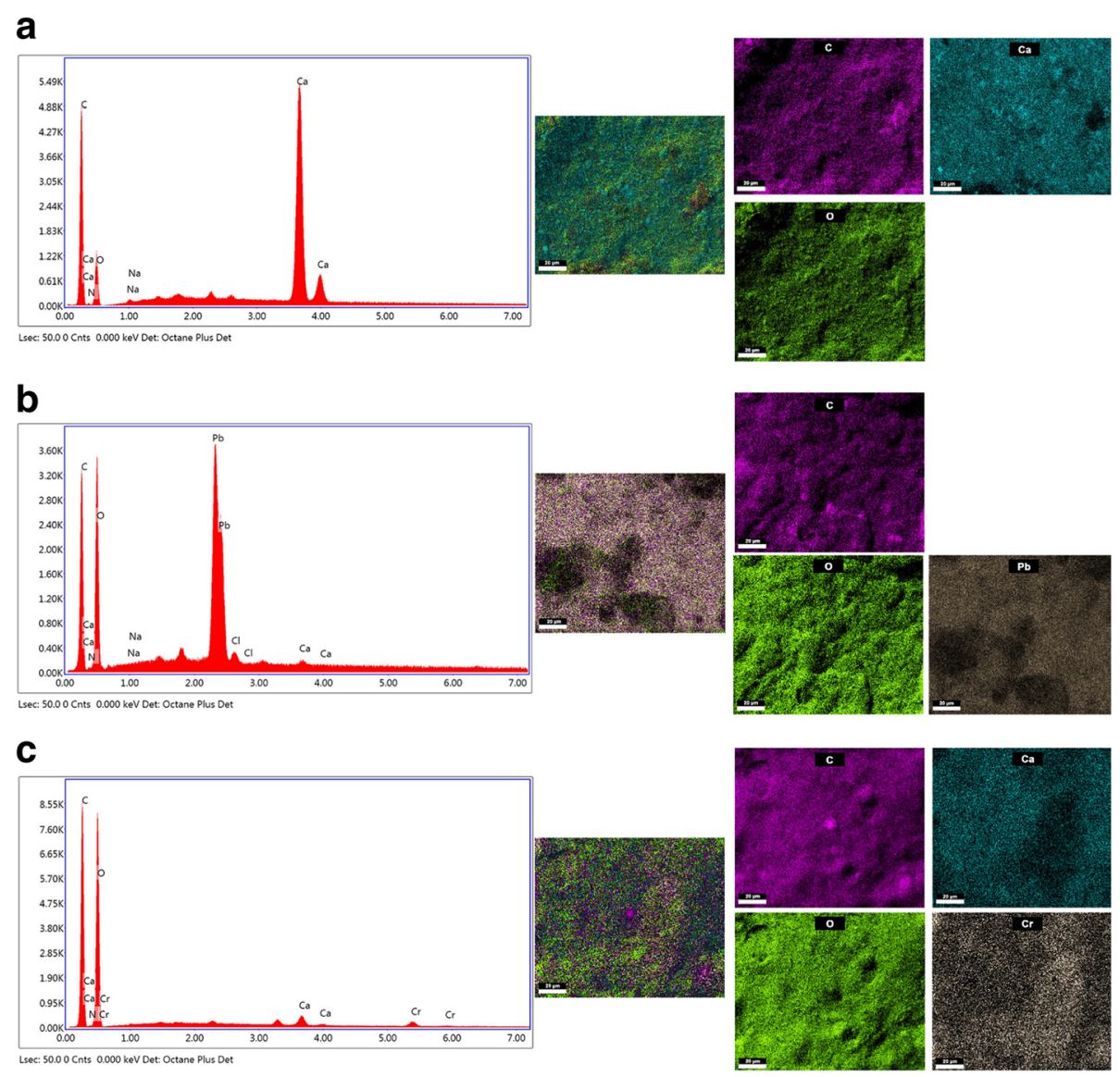

Fig. 4 EDX and elemental mapping of the CSM/SA hybrid beads: a before metal adsorption, $\mathbf{b}$ after Pb(II) loading, $\mathbf{c}$ after $\mathrm{Cr}(\mathrm{VI})$ loading

lead adsorption. In other words, the calcium element was totally removed from CSM/SA adsorbent. This characteristic suggests that the ion exchange might be the main mechanism governing the removal of lead ions from aqueous solutions. The presence of $\mathrm{Cl}$ element is probably due to chloride ions from lead chloride solution used in the adsorption process.

In addition, the images of elemental mapping show that chromium $(2.3 \%)$ is uniformly distributed along the surface of CSM/SA adsorbent. In comparison, the bright contrast spots of $\mathrm{Ca}(10.5 \%)$ were more solidly dispersed at the adsorbent surface as depicted in Fig. 4b. This result suggests that the adsorption mechanism of chromium in the hybrid beads is controlled only by electrostatic attractions [31].

To sum up, based on FTIR, SEM and EDX analyses, the mechanism of $\mathrm{Pb}(\mathrm{II})$ removal by CSM/SA hybrid beads was governed by ion exchange between calcium on the adsorbent surface and lead ions in the aqueous solution [12]. Probably, the mechanism for $\mathrm{Cr}(\mathrm{VI})$ removal includes mainly electrostatic attractions (Fig. 5).
Factors affecting removal of $\mathrm{Pb}(\mathrm{II})$ and $\mathrm{Cr}(\mathrm{VI})$ ions

Several parameters affect the adsorption efficiency, such as $\mathrm{pH}, \mathrm{pH}_{\mathrm{pzc}}$, adsorbent dose, initial metals concentration and temperature.

According to literature, the most important factor influencing the adsorption capacity and removal efficiency of $\mathrm{CSM} / \mathrm{SA}$ is the initial $\mathrm{pH}$ value of the solution. From Fig. 6a, the adsorption of $\mathrm{Pb}(\mathrm{II})$ and $\mathrm{Cr}(\mathrm{VI})$ was very dependent on $\mathrm{pH}$ mainly because it affects the solubility of metal ions and the adsorbent surface charge [14]. Increasing the $\mathrm{pH}$ from 3 to 5 resulted a slight enhancement in the adsorption capacity of $\mathrm{Pb}(\mathrm{II})$ from 160 to $164 \mathrm{mg} \mathrm{g}^{-1}$, respectively. No precipitation of lead hydroxide or protonation of the carboxyl group occurred in this $\mathrm{pH}$ range [12]. However, when the $\mathrm{pH}$ value was above 6 , the precipitation of insoluble lead hydroxide was observed, inducing a decrease in the removal of $\mathrm{Pb}$ (II) ions. Concerning $\mathrm{Cr}(\mathrm{VI})$ elimination, the adsorption capacity decreases with increasing $\mathrm{pH}$ value, producing a significant reduction in $\mathrm{Cr}(\mathrm{VI})$ through basic $\mathrm{pH}$ values. As shown in Fig. 6a, when the $\mathrm{pH}$ increasing from 3.0 to 7.0 , the quantity of $\mathrm{Cr}(\mathrm{VI})$ adsorbed onto CSM/SA at equilibrium decreases from 5.0 


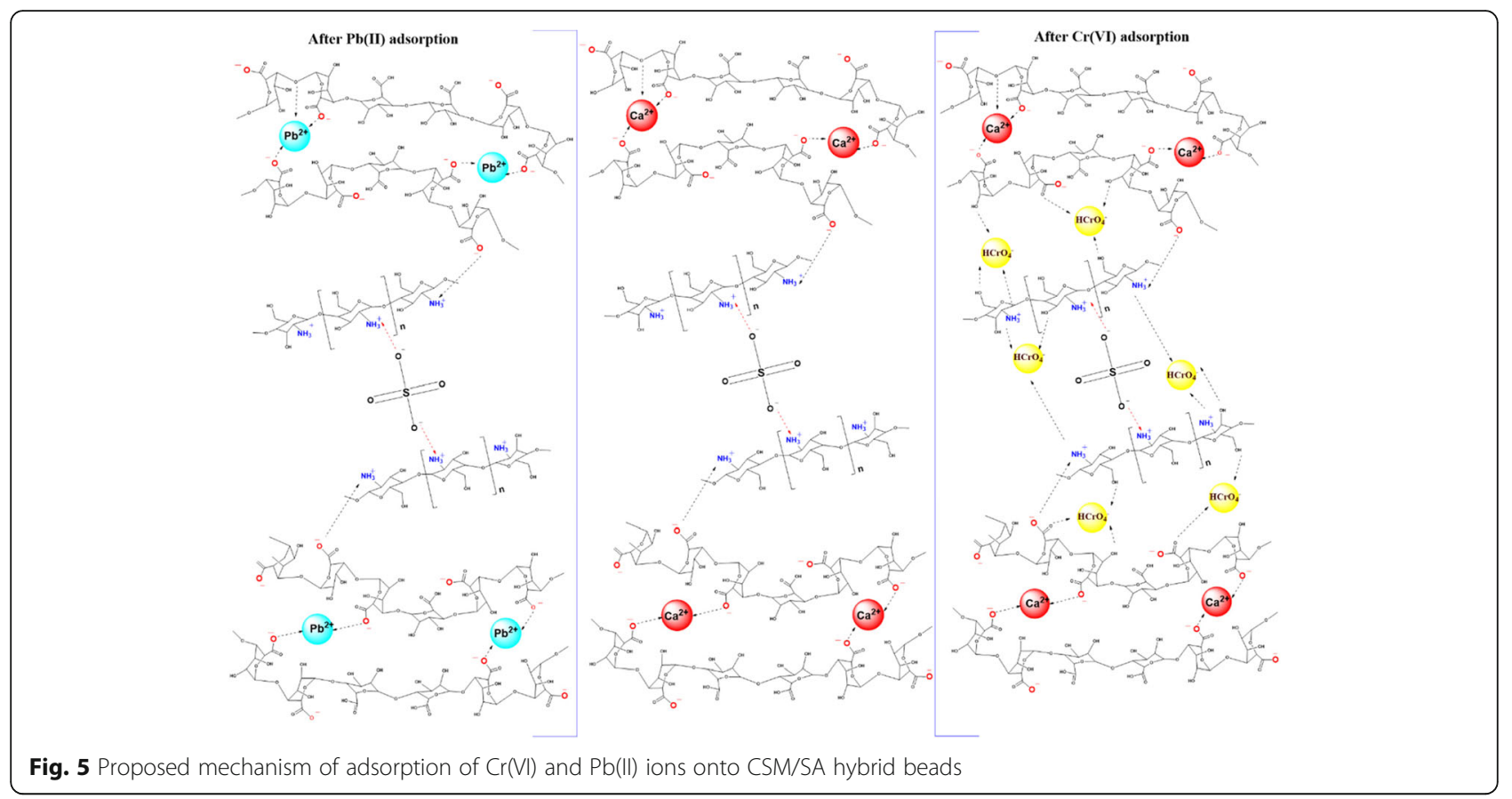

to $0.5 \mathrm{mg} \mathrm{g}^{-1}$. At different $\mathrm{pH}$ levels, it is important to remember that $\mathrm{Cr}(\mathrm{VI})$ can occur in various forms: $\mathrm{CrO}_{4}^{-}$, $\mathrm{Cr}_{2} \mathrm{O}_{7}^{2-} \mathrm{HCrO}_{4}^{-}$, and $\mathrm{H}_{2} \mathrm{CrO}_{4}^{-}$[32]. When the $\mathrm{pH}$ of the medium is between 2 and 4, the predominant specie will be $\mathrm{HCrO}_{4}^{-}$, and amine groups are easily protonated to produce $\mathrm{NH}_{3}{ }^{+}$species present in CSM/SA surface which increases the electrostatic attraction between the anionic chromium and the protonated amine functionalities. Therefore, the $\mathrm{pH}$ of 3.0 and 5.2 could be selected as an optimum $\mathrm{pH}$ values for the consequent experiments for $\mathrm{Cr}(\mathrm{VI})$ and $\mathrm{Pb}(\mathrm{II})$, respectively.

$\mathrm{pH}_{\mathrm{pzc}}$ is another important parameter, where the PZC of the adsorbent governs the adsorption process. It is the $\mathrm{pH}$ value where the net surface charge of the adsorbent corresponds to zero, and it offers the possible mechanism about the electrostatic interaction between adsorbent and adsorbate [33]. At a pH below 6.6 (Fig. 6b), the CSM/SA surface is positively charged. The functional groups such as $\mathrm{NH}_{3}{ }^{+}, \mathrm{H}_{3} \mathrm{O}^{+}, \mathrm{COOH}^{+}$ were protonated and positively charged, thus preventing metal adsorption due to electrostatic repulsion [5]. There might be another adsorption mode such as cationic exchange with the protonated carboxylic groups in acidic solutions, ionic exchange between calcium ions bound and carboxyl groups by complexation of metal cations on carboxylate, amino and hydroxyls groups present in CSM/SA adsorbent surface [7]. For a $\mathrm{pH}<3$, most of the carboxylate groups are protonated. In this case, the mechanism in metal binding should be ion-exchange between protons and free metal cations [34]. When the $\mathrm{pH}$ value was increased, the deprotonation of carboxylic acid and amino groups allows the ionic exchange between $\mathrm{Pb}^{2+}$ and $\mathrm{Ca}^{2+}$ ions. This was confirmed by EDX and elemental mapping before and after adsorption (Fig. 4). Similar results was reported by Gopalakannan and Viswanathan [19]. The positively charged surface at $\mathrm{pH}<6.6$ promotes the retention of anionic contaminants. At an initial $\mathrm{pH}=2, \mathrm{Cr}(\mathrm{VI})$ mainly exists in anionic form $\left(\mathrm{HCrO}_{4}^{-}\right)$. According to the $\mathrm{pH}$ and $\mathrm{pH}_{\mathrm{pzc}}$ results, the electrostatic attraction between anionic $\mathrm{HCrO}_{4}^{-}$and the positively charged surface of the CSM/SA is responsible for $\mathrm{Cr}(\mathrm{VI})$ adsorption.

The adsorption time is one of the principal parameters that influences the elimination toxic species from aqueous solution [29]. The influence of contact time on the elimination efficiency of $\mathrm{Pb}(\mathrm{II})$ and $\mathrm{Cr}(\mathrm{VI})$ ions using CSM/SA hybrid beads is illustrated in Fig. 6c. During first $115 \mathrm{~min}$ of the process, it was noticed that the removal efficiencies of $\mathrm{Cr}(\mathrm{VI})$ and $\mathrm{Pb}(\mathrm{II})$ were 6 and $45 \%$, respectively. By increasing the contact time to $190 \mathrm{~min}$, the pervious adsorbed values of $\mathrm{Cr}(\mathrm{VI})$ and $\mathrm{Pb}(\mathrm{II})$ increased gradually to 7 and 55\%, respectively. After 200 $\mathrm{min}$ to the end of shaking time, the values of removal efficiency were nearly constant due to the saturation of active sites and the attainment of dynamic equilibrium stage. The metal ions removed by CSM/SA adsorbent reached the equilibrium after $200 \mathrm{~min}$ for $\mathrm{Pb}(\mathrm{II})$ and $220 \mathrm{~min}$ for $\mathrm{Cr}(\mathrm{VI})$. Therefore, 200 and $220 \mathrm{~min}$ could be considered as the equilibrium time. 

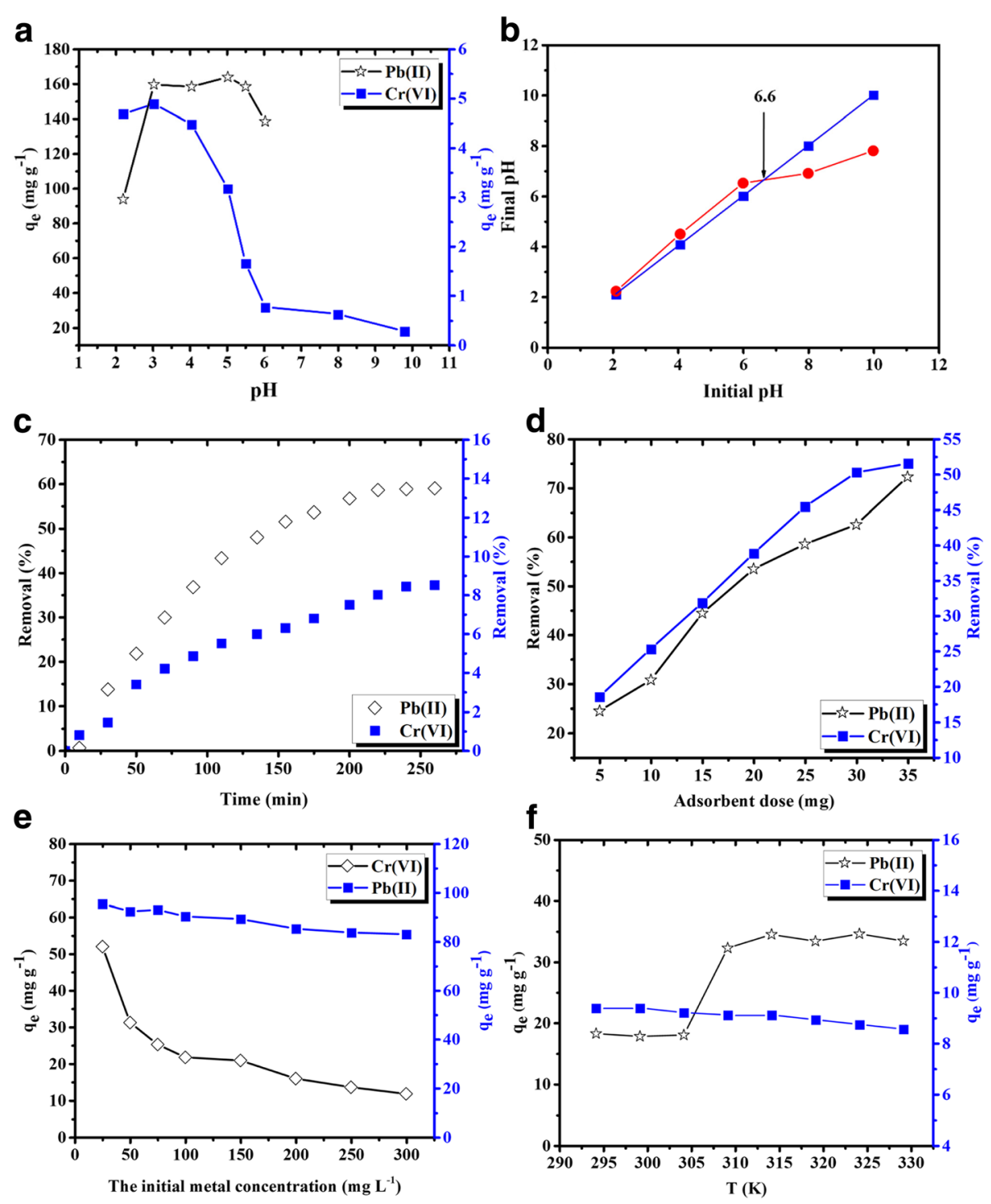

Fig. 6 a Effect of the initial $\mathrm{pH}$ [initial concentration of $\mathrm{Pb}(\mathrm{II})$ and $\mathrm{Cr}(\mathrm{VI}): 100 \mathrm{mg} \mathrm{L}^{-1}$; adsorbent dose: $0.06 \mathrm{~g}$; $\mathrm{T}=25^{\circ} \mathrm{C}$; contact time: $135 \mathrm{~min}$ ], b point of zero charge, c contact time [initial concentration of $\mathrm{Pb}(\mathrm{II})$ and $\mathrm{Cr}(\mathrm{VI}): 100 \mathrm{mg} \mathrm{L}^{-1}$; adsorbent dose: $0.06 \mathrm{~g}$; $\mathrm{T}=25^{\circ} \mathrm{C}$; initial pH for $\mathrm{Pb}(\mathrm{II})$ and $\mathrm{Cr}(\mathrm{VI}) ; 3.0$ and 5.2], $\mathbf{d}$ adsorbent dose [initial concentration of $\mathrm{Pb}(\mathrm{II})$ and $\mathrm{Cr}(\mathrm{VI}): 100 \mathrm{mg} \mathrm{L}^{-1} ; \mathrm{T}=25^{\circ} \mathrm{C}$; initial $\mathrm{pH}$ for $\mathrm{Pb}(\mathrm{II})$ and $\mathrm{Cr}(\mathrm{VI}) ; 3.0$ and 5.2 ; contact time: $250 \mathrm{~min}]$, e initial metal concentration $\left[T=25^{\circ} \mathrm{C}\right.$; initial $\mathrm{pH}$ for $\mathrm{Pb}(\mathrm{II})$ and $\mathrm{Cr}(\mathrm{Vl})$; 3.0 and 5.2; contact time: $250 \mathrm{~min}$; adsorbent dose: $0.06 \mathrm{~g}$ ] and $\mathbf{f}$ temperature [initial concentration of $\mathrm{Pb}(\mathrm{II})$ and $\mathrm{Cr}(\mathrm{VI}): 100 \mathrm{mg} \mathrm{L}^{-1}$; adsorbent dose: $0.06 \mathrm{~g}$; contact time: 135 min; adsorbent dose: $0.06 \mathrm{~g}$ ] for the adsorption of $\mathrm{Pb}(\mathrm{II})$ and $\mathrm{Cr}(\mathrm{VI})$ onto CSM/SA hybrid beads

The influence of adsorbent dose on the percentage of metal ion removal under optimal conditions was studied. According to Fig. 6d, the amount of adsorbent used during the adsorption influenced the removal percentage. The adsorption of $\mathrm{Pb}(\mathrm{II})$ and $\mathrm{Cr}(\mathrm{VI})$ ions was attained about 25 and $17 \%$ removals when $5 \mathrm{mg}$ of CSM/SA hybrid beads were used. At the highest adsorbent amount (35 mg), the elimination efficiency reaches $72 \%$ for $\mathrm{Pb}(\mathrm{II})$ and $51 \%$ for $\mathrm{Cr}(\mathrm{VI})$. These may be attributed to the presence of greater number of adsorbent sites and surface area at higher adsorbent dose.
Initial metal ion concentration plays an imperative role in the adsorption of metal ions. The adsorption was studied using the different initial concentrations of metal ions $\left(25-300 \mathrm{mg} \mathrm{L}^{-1}\right)$, the results shows that the percentage of elimination decreases with increasing the initial metal ion concentration due to the saturation of the adsorption sites on the CSM/SA adsorbent surface as illustrated in Fig. 6e. However, the quantity of metal ions adsorbed per unit weight of adsorbent $\left(\mathrm{mgg}^{-1}\right)$ was found to increase with increasing initial concentration. The capacity was 40,156 and $160 \mathrm{mg} \mathrm{g}^{-1}$ respectively 
for the initial $\mathrm{Pb}(\mathrm{II})$ concentration 25, 100 and $300 \mathrm{mg}$ $\mathrm{L}^{-1}$. While for $\mathrm{Cr}(\mathrm{VI})$, the adsorption capacities for the initial concentration 25,100 and $300 \mathrm{mg} \mathrm{L}^{-1}$ are 6,8 and $14 \mathrm{mg} \mathrm{g}^{-1}$, individually. However, with additional increase of the initial metal ion concentration, the adsorption capacities enhanced slowly or even continued unaffected, signifying that the number of active sites on CSM/SA adsorbent could be the factor limiting its adsorption capacities. Therefore, the maximum adsorption value of metal ions on adsorbent was obtained at higher concentration of metal ions due to saturation of available active sites.

Environmental temperature is a significant factor that can influence the efficiency of the adsorbent during the adsorption process [35]. The adsorption capacities were compared at different stabilized temperatures under the same experimental conditions for CSM/SA adsorbent. Figure $6 \mathrm{f}$ reveals that the adsorption of $\mathrm{Pb}$ (II) was increased after raising the temperature from 30 to $55^{\circ} \mathrm{C}$, resulting in an enhancement of adsorption capacity, which indicates an endothermic process. On the other hand, the chromium removal is independent of temperature.

\section{Data analysis of the adsorption kinetics}

The adsorption kinetics data of $\mathrm{Pb}(\mathrm{II})$ and $\mathrm{Cr}(\mathrm{VI})$ on CSM/SA adsorbent were studied using three different kinetic models: pseudo-first-order, pseudo-second-order and intraparticle diffusion models [33], which are usually expressed, respectively, as follow:

$$
\begin{aligned}
& \log \left(q_{e}-q_{t}\right)=\log q_{e}-\left(\frac{k_{1}}{2.303}\right) t \\
& \frac{1}{q_{t}}=\frac{1}{k_{2} q_{e}^{2}} \times \frac{1}{t}+\frac{1}{q_{e}} \\
& q_{t}=k \cdot t^{1 / 2}+C
\end{aligned}
$$

Where $k_{2}$ represents the second-order rate constant $\left(\mathrm{g} \mathrm{mg}^{-1} \mathrm{~min}\right), \mathrm{q}_{\mathrm{e}}$ and $\mathrm{q}_{\mathrm{t}}$ are adsorption capacities $\left(\mathrm{mg} \mathrm{g}^{-1}\right)$ corresponding to equilibrium and time $\mathrm{t}(\mathrm{min})$, respectively. $k_{1}$ is the pseudo-first order rate constant $\left(\mathrm{min}^{-1}\right)$ and $\mathrm{k}\left(\mathrm{mg} \mathrm{g}^{-1} \mathrm{~min}^{-1 / 2}\right)$ is the intra-particle diffusion constant. The kinetics plots for metal ions absorption onto CSM/SA adsorbent are presented in Fig. 7.

The kinetic parameters and coefficient of determination $\mathrm{R}^{2}$ for adsorption of metal ions on CSM/SA adsorbent were determined by linear regression analysis (Table 1). It indicates that for $\mathrm{Pb}(\mathrm{II})$ the pseudo-first-order model present the best sorption process with a highest coefficient of determination $\left(R^{2}>0.99\right)$ compared to the pseudosecond-order model $\left(R^{2}<0.95\right)$. This result designates that the adsorption process of $\mathrm{Pb}(\mathrm{II})$ is complicated in rate-determining step. For $\mathrm{Cr}(\mathrm{VI})$ adsorption, according to the correlation coefficients $\left(R^{2}>0.99\right)$, the adsorption

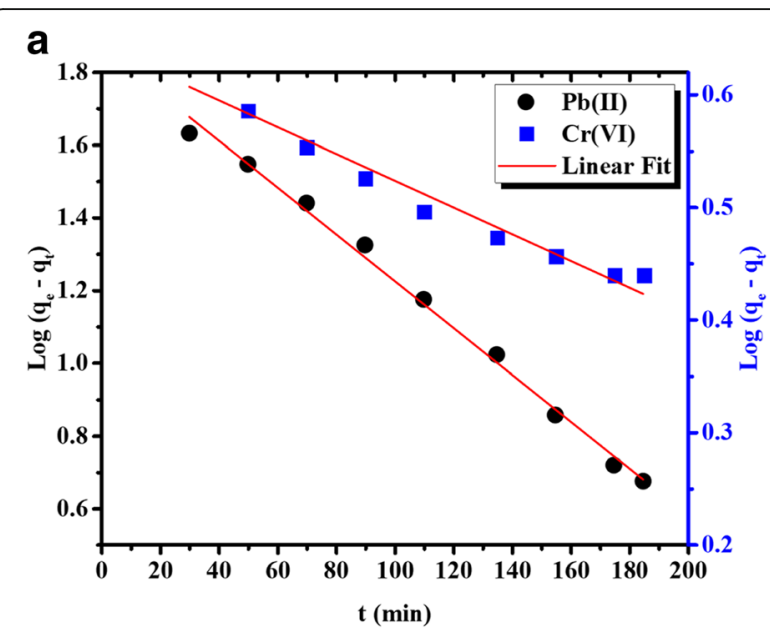

b
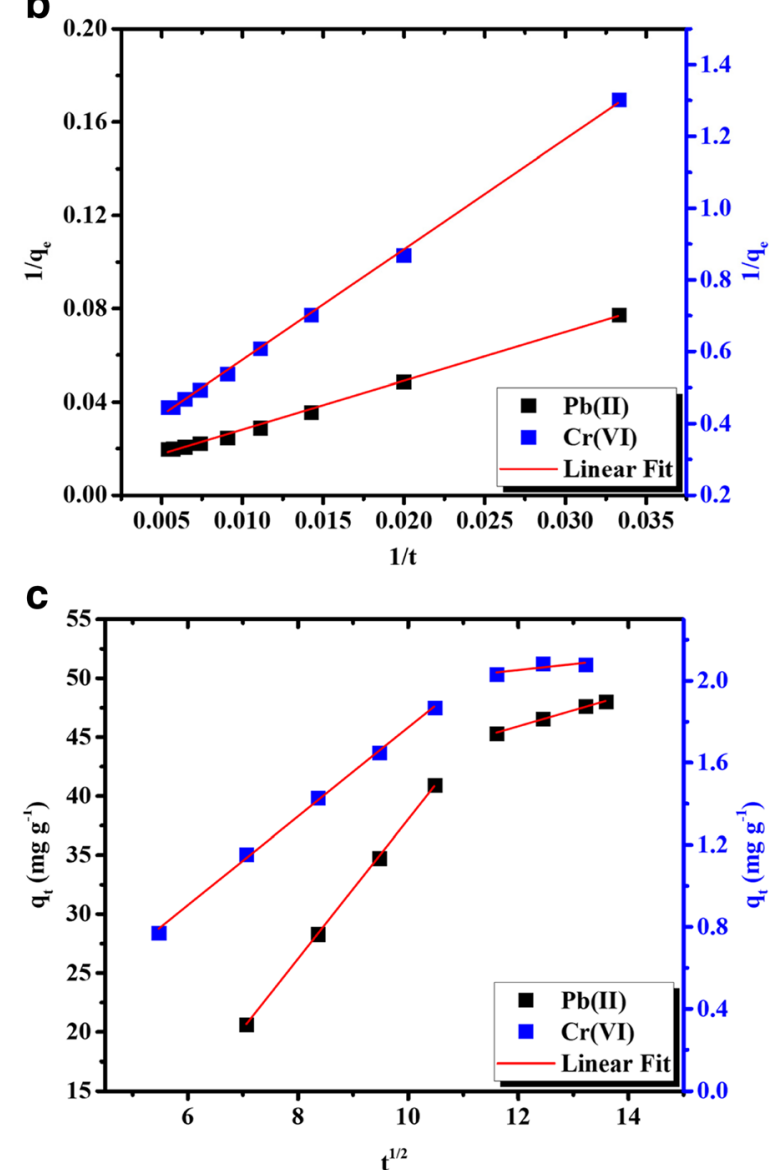

Fig. 7 The pseudo-first-order (a), pseudo-second-order (b) and intraparticle diffusion (c) plot for $\mathrm{Pb}(\mathrm{II})$ and $\mathrm{Cr}(\mathrm{VI})$ ions adsorption onto CSM/SA hybrid beads

process fits well the pseudo-second-order model and the theoretical values $\left(\mathrm{q}_{\mathrm{e}} \mathrm{cal}\right)$ was close to the experimental values $\left(\mathrm{q}_{\mathrm{e}}\right)$.

The mechanism of metal ion adsorption was studied by the intra-particle diffusion model by plotting the 
Table 1 Kinetic parameters for the adsorption of $\mathrm{Pb}(\mathrm{II})$ and $\mathrm{Cr}(\mathrm{VI})$ ion onto CSM/SA hybrid beads

\begin{tabular}{|c|c|c|c|c|c|c|c|c|c|}
\hline \multirow[b]{2}{*}{ Ion } & \multirow[b]{2}{*}{$q_{e} \exp \left(\mathrm{mg} \mathrm{g}^{-1}\right)$} & \multicolumn{3}{|c|}{ Pseudo-first-order } & \multicolumn{3}{|c|}{ Pseudo-second-order } & \multicolumn{2}{|c|}{ Intraparticle Diffusion } \\
\hline & & $\mathrm{q}_{\mathrm{e}} \mathrm{cal}\left(\mathrm{mg} \mathrm{g}^{-1}\right)$ & $k_{1}\left(\min ^{-1}\right)$ & $R^{2}$ & $\overline{\mathrm{q}_{\mathrm{e}} \mathrm{cal}\left(\mathrm{mg} \mathrm{g}^{-1}\right)}$ & $\mathrm{k}_{2}\left(\mathrm{~g} \mathrm{mg}^{-1} \mathrm{~min}^{-1}\right)$ & $R^{2}$ & $\mathrm{k}\left(\mathrm{mg} \mathrm{g}^{-1} \mathrm{~min}^{-1 / 2}\right)$ & $R^{2}$ \\
\hline $\mathrm{Pb}(I)$ & 51 & 74 & 0.014 & 0.995 & 86 & 0.0022 & 0.949 & 4.9 & 0.884 \\
\hline $\operatorname{Cr}(\mathrm{VI})$ & 2.2 & 4.4 & 0.0027 & 0.967 & 3.6 & 0.0025 & 0.997 & 0.19 & 0.989 \\
\hline
\end{tabular}

amount of the adsorbed metal at time $\mathrm{t}\left(\mathrm{q}_{\mathrm{t}}\right)$ and the square root of time $\left(\mathrm{t}^{1 / 2}\right)$. According to this model, if the plot of $\mathrm{q}_{t}$ versus $\mathrm{t}^{1 / 2}$ gives a straight line, then the adsorption process is governed by intra-particle diffusion, and if the data reveal multi-linear plots, then two or more steps rule the adsorption process [36]. From Fig. 7c, the graph presents two distant linear plots, which indicates that the adsorption process was not governed uniquely by intraparticle diffusion. In the linear part, the adsorption rate of $\mathrm{Pb}(\mathrm{II})$ and $\mathrm{Cr}(\mathrm{VI})$ ions is high due to the external surface adsorption. The second plateau indicated the slowing of intra-particle pore diffusion.

\section{Adsorption isotherms}

To determine the maximum metal adsorption capacities of CSM/SA hybrid beads, Langmuir (Eq. (7)) and Freundlich (Eq. (8)) isotherms models have been used [33]. Both models can be computed by the following equation:

$$
\begin{aligned}
& \frac{1}{q_{e}}=\frac{1}{b C_{e} k_{L}}+\frac{1}{b} \\
& \ln q_{e}=\frac{1}{n} \ln C_{e}+\ln k_{f}
\end{aligned}
$$

Where $\mathrm{q}_{\mathrm{e}}$ is the amount of metal ions adsorbed per unit weight of the adsorbent $\left(\mathrm{mg} \mathrm{g}^{-1}\right) . \mathrm{C}_{e}$ is the equilibrium concentration of metal ions in solution $\left(\mathrm{mg} \mathrm{L}^{-1}\right), \mathrm{b}\left(\mathrm{L} \mathrm{mg}^{-1}\right)$ is Langmuir isotherm constant that relates to the energy of adsorption, $\mathrm{K}_{\mathrm{L}}$ is the Langmuir equilibrium constant, $K_{F}$ specifies the adsorption capacity and $1 / \mathrm{n}$ is a numerical value associated to the adsorption intensity.

To evaluate the adsorption process according to Langmuir isotherm, a separation factor was calculated as follow (Eq. (9)):

$$
R_{L}=\frac{1}{1+b C_{0}}
$$

The simulating curves of the Langmuir and Freundlich models are shown in Fig. 8. The fitted constants with regression coefficients $\left(R^{2}\right)$ are summarized in Table 2. It was found that the obtained adsorption data are in accordance to the Langmuir isotherm model with $\mathrm{R}^{2}=$ 0.992 and 0.979 for $\mathrm{Pb}(\mathrm{II})$ and $\mathrm{Cr}(\mathrm{VI})$, respectively. The maximum adsorption capacity of CSM/SA hybrid beads were 189 and $16 \mathrm{mg} \mathrm{g}^{-1}$ for $\mathrm{Pb}(\mathrm{II})$ and $\mathrm{Cr}(\mathrm{VI})$, respectively. These values are much higher than those reported by Ren et al. [31] for sodium alginate-carboxymethyl cellulose gel beads $\left(1.7 \mathrm{mg} \mathrm{g}^{-1}\right)$ [34]. The $\mathrm{R}_{\mathrm{L}}$ values are in the range of $0<R_{L}<1$, which indicate that the adsorption of chromium and lead by CSM/SA adsorbent was favorable.

It is encouraging to compare our findings with those reported in literature with other adsorbents.

The maximum adsorption capacities of $\mathrm{Pb}(\mathrm{II})$ and $\mathrm{Cr}(\mathrm{VI})$ on chitosan and alginate adsorbents reported in the literature are listed in Table 3.

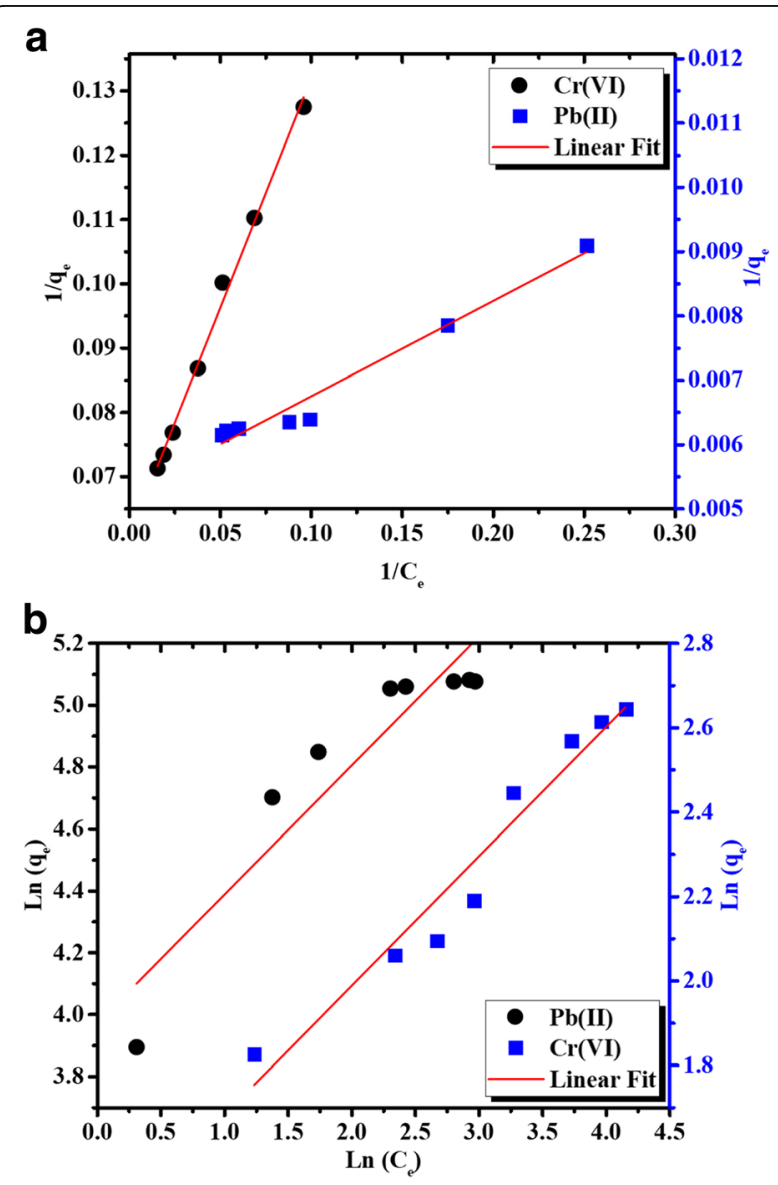

Fig. 8 Langmuir a and Freundlich $\mathbf{b}$ isotherms for $\mathrm{Pb}(\mathrm{II})$ and $\mathrm{Cr}(\mathrm{VI})$ adsorption onto CSM/SA hybrid beads 
Table 2 Various isotherms parameters of $\mathrm{Pb}(\mathrm{II})$ and $\mathrm{Cr}(\mathrm{VI})$ ions adsorption onto CSM/SA hybrid beads

\begin{tabular}{|c|c|c|c|c|c|c|c|c|}
\hline \multirow[b]{2}{*}{ Ion } & \multirow[b]{2}{*}{$\begin{array}{l}\mathrm{q}_{\mathrm{e}} \text { exp. } \\
\left(\mathrm{mg} \mathrm{g}^{-1}\right)\end{array}$} & \multirow[b]{2}{*}{$\begin{array}{l}\mathrm{q}_{\max } \\
\left(\mathrm{mg} \mathrm{g}^{-1}\right)\end{array}$} & \multicolumn{3}{|l|}{ Langmuir } & \multicolumn{3}{|l|}{ Freundlich } \\
\hline & & & $\begin{array}{l}\mathrm{K}_{\mathrm{L}} \\
\left(\mathrm{L} \mathrm{mg}^{-1}\right)\end{array}$ & $\mathrm{R}_{\mathrm{L}}$ & $R^{2}$ & $\begin{array}{l}\mathrm{K}_{\mathrm{F}} \\
\left(\left(\mathrm{mg} \mathrm{g}^{-1}\right)\right. \\
\left.\left(\mathrm{L} \mathrm{mg}^{-1}\right)^{1 / n}\right)\end{array}$ & $\mathrm{N}$ & $R^{2}$ \\
\hline $\mathrm{Pb}(\mathrm{II})$ & 161 & 189 & 0.34 & 0.021 & 0.992 & 10.6 & 2.07 & 0.915 \\
\hline $\mathrm{Cr}(\mathrm{VI})$ & 14 & 16 & 24 & 0.0063 & 0.979 & 3.9 & 3.26 & 0.949 \\
\hline
\end{tabular}

Table 3 Maximum adsorption capacity of different adsorbents based biopolymers used for the removal of $\mathrm{Pb}(\mathrm{II})$ and $\mathrm{Cr}(\mathrm{VI})$

\begin{tabular}{lllll}
\hline Adsorbents & \multicolumn{2}{l}{$\begin{array}{l}\mathrm{q}_{\max } \\
\left(\mathrm{mg} \mathrm{g}^{-1}\right)\end{array}$} & \\
\cline { 2 - 3 } & $\mathrm{Pb}(\mathrm{II})$ & $\mathrm{Cr}(\mathrm{VI})$ & \\
\hline $\begin{array}{l}\text { Chitosan microsphences } \\
\text { alginate hybrid beads }\end{array}$ & 189 & 16 & This study \\
$\begin{array}{l}\text { Chitosan alginate-beads } \\
\text { Chitosan-crosslinked-poly(alginic acid) }\end{array}$ & - & 24 & - & {$[37]$} \\
nanohydrogel & & & {$[38]$} \\
Sodium alginate-polyanilinenanofibers & - & 73 & {$[39]$} \\
Chitosan coated calcium alginate beads & 107 & - & {$[14]$} \\
Graphite doped chitosan composite & 6.7 & - & {$[40]$} \\
Silica nanopowders/alginate composite & 83 & - & {$[41]$} \\
\hline
\end{tabular}

\section{Conclusions}

The present study was undertaken to evaluate the efficiency of newly developed green adsorbent based on chitosan microspheres/sodium alginate hybrid beads for the elimination of $\mathrm{Cr}(\mathrm{VI})$ and $\mathrm{Pb}(\mathrm{II})$ in aqueous synthetic solutions. Resultant hybrid beads were characterized by TGA, DSC, FTIR, SEM with EDX elemental mapping and were subjected for metal ion removal in batch process. The most obvious findings to emerge from this study are summing as follows:

1. TGA/DTA and DSC analyses of the prepared CSM/ SA beads reveals high thermal stability.

2. FTIR results indicate mutual interaction between chitosan microspheres and sodium alginate.

3. The surface characterizations of the adsorbent confirm the distinct morphology and characteristics of chitosan microspheres dispersed in sodium alginate matrix before and after adsorption.

4. EDX elemental mapping confirms that the quantity of adsorbed $\mathrm{Pb}^{2+}$ ions is directly correlated to the amount of $\mathrm{Ca}^{2+}$ at the surface of CSM/SA hybrid beads. However, the electrostatic attraction is responsible for chromium retention.

5. CSM/SA green adsorbent shows high adsorption capacity of 188 and $16 \mathrm{mg} \mathrm{g}^{-1}$ for $\mathrm{Pb}(\mathrm{II})$ and $\mathrm{Cr}(\mathrm{VI})$, respectively.
6. Equilibrium data fitted very well to the Langmuir isotherm, confirming the monolayer adsorption capacity of both ions onto CSM/SA hybrid beads.

These findings clearly demonstrate that chitosan microspheres/sodium alginate hybrid beads are expected to be economically viable for large-scale removal of $\mathrm{Pb}(\mathrm{II})$ and $\mathrm{Cr}(\mathrm{VI})$ ions from aqueous solutions.

\section{Acknowledgments}

The authors gratefully acknowledge Center of Analysis and Characterization (CAC) - Cadi Ayyad University (Morocco) for providing instrumental facilities for sample characterizations.

\section{Authors' contributions}

The manuscript was mainly based on a draft written by EA, and written through contributions of all authors. All authors read and and approved the final manuscript.

\section{Competing interests}

The authors declare that they have no competing interests.

\section{Publisher's Note}

Springer Nature remains neutral with regard to jurisdictional claims in published maps and institutional affiliations.

Received: 23 June 2018 Accepted: 13 November 2018

Published online: 19 March 2019

\section{References}

1. Dutta K, De S. Aromatic conjugated polymers for removal of heavy metal ions from wastewater: a short review. Environ Sci Wat Res. 2017:3:793-805.

2. Abdel-Halim ES, Al-Deyab SS. Removal of heavy metals from their aqueous solutions through adsorption onto natural polymers. Carbohyd Polym. 2011; 84:454-8.

3. Eladlani N, Dahmane E, Ouahrouch A, Rhazi M, Taourirte M. Recovery of chromium(III) from tannery wastewater by nanoparticles and whiskers of chitosan. J Polym Environ. 2018;26:152-7.

4. Kan CC, Ibe AH, Rivera KKP, Arazo RO, de Luna MDG. Hexavalent chromium removal from aqueous solution by adsorbents synthesized from groundwater treatment residuals. Sustain Environ Res. 2017;27:163-71.

5. Liu W, Zhang JS, Jin YJ, Zhao X, Cai ZQ. Adsorption of Pb(II), cd(II) and Zn(II) by extracellular polymeric substances extracted from aerobic granular sludge: efficiency of protein. J Environ Chem Eng. 2015;3:1223-32.

6. Shahabuddi S, Tashakori C, Kamboh MA, Korrani ZS, Saidur R, Nodeh HR, et al. Kinetic and equilibrium adsorption of lead from water using magnetic metformin-substituted SBA-15. Environ Sci Wat Res. 2018;4:549-58.

7. Wang SY, Vincent T, Roux JC, Faur C, Guibal E. Pd(II) and Pt(IV) sorption using alginate and algal-based beads. Chem Eng J. 2017;313:567-79.

8. Kyzas GZ, Kostoglou M. Green adsorbents for wastewaters: a critical review. Materials. 2014;7:333-64.

9. Algothmi WM, Bandaru NM, Yu Y, Shapter JG, Ellis AV. Alginate-graphene oxide hybrid gel beads: an efficient copper adsorbent material. J Colloid Interf Sci. 2013;397:32-8.

10. Ahmad M, Manzoor K, Ikram S. Versatile nature of hetero-chitosan based derivatives as biodegradable adsorbent for heavy metal ions; a review. Int J Biol Macromol. 2017;105:190-203.

11. Sun XT, Li Q, Yang LR, Liu HZ. Chemically modified magnetic chitosan microspheres for $\mathrm{Cr}(\mathrm{VI})$ removal from acidic aqueous solution. Particuology. 2016;26:79-86.

12. Wang $Z Q$, Huang $Y G$, Wang $M$, Wu GH, Geng $T M$, Zhao $Y G$, et al. Macroporous calcium alginate aerogel as sorbent for $\mathrm{Pb}^{2+}$ removal from water media. J Environ Chem Eng. 2016;4:3185-92.

13. Cataldo S, Gianguzza A, Milea D, Muratore N, Pettignano A. Pb(II) adsorption by a novel activated carbon - alginate composite material. A kinetic and equilibrium study. Int J Biol Macromol. 2016;92:769-78. 
14. Mousa NE, Simonescu CM, Patescu RE, Onose C, Tardei C, Culita DC, et al. $\mathrm{Pb}^{2+}$ removal from aqueous synthetic solutions by calcium alginate and chitosan coated calcium alginate. React Funct Polym. 2016;109:137-50.

15. Gopalakannan V, Viswanathan N. Development of nano-hydroxyapatite embedded gelatin biocomposite for effective chromium(VI) removal. Ind Eng Chem Res. 2015;54:12561-9.

16. Kong DL, Wang N, Qiao N, Wang Q, Wang Z, Zhou ZY, et al. Facile preparation of ion-imprinted chitosan microspheres enwrapping $\mathrm{Fe}_{3} \mathrm{O}_{4}$ and graphene oxide by inverse suspension cross-linking for highly selective removal of copper(II). ACS Sustain Chem Eng. 2017;5:7401-9.

17. Tolaimate A, Desbrieres J, Rhazi M, Alagui A, Vincendon M, Vottero P. On the influence of deacetylation process on the physicochemical characteristics of chitosan from squid chitin. Polymer. 2000;41:2463-9.

18. Berthold A, Cremer K, Kreuter J. Preparation and characterization of chitosan microspheres as drug carrier for prednisolone sodium phosphate as model for antiinflammatory drugs. J Control Release. 1996;39:17-25.

19. Gopalakannan V, Viswanathan N. One pot synthesis of metal ion anchored alginate-gelatin binary biocomposite for efficient $\mathrm{Cr}(\mathrm{VI})$ removal. Int J Biol Macromol. 2016;83:450-9.

20. Soares JP, Santos JE, Chierice GO, Cavalheiro ETG. Thermal behavior of alginic acid and its sodium salt. Eclet Quim. 2004;29:57-63.

21. Schnepp Z, Wimbush SC, Mann S, Hall SR. Alginate-mediated routes to the selective synthesis of complex metal oxide nanostructures. Crystengcomm. 2010;12:1410-5

22. Ross AB, Hall C, Anastasakis K, Westwood A, Jones JM, Crewe RJ. Influence of cation on the pyrolysis and oxidation of alginates. J Anal Appl Pyrol. 2011;91:344-51.

23. Brugnerotto J, Lizardi J, Goycoolea FM, Arguelles-Monal W, Desbrieres J, Rinaudo M. An infrared investigation in relation with chitin and chitosan characterization. Polymer. 2001;42:3569-80.

24. Vijayalakshmi K, Devi BM, Latha S, Gomathi T, Sudha PN, Venkatesan J, et al. Batch adsorption and desorption studies on the removal of lead (II) from aqueous solution using nanochitosan/sodium alginate/microcrystalline cellulose beads. Int J Biol Macromol. 2017:104:1483-94.

25. Abdelmalek BE, Sila A, Haddar A, Bougatef A, Ayadi MA. $\beta$-chitin and chitosan from squid gladius: biological activities of chitosan and its application as clarifying agent for apple juice. Int J Biol Macromol. 2017;104: 953-62.

26. Afshar HA, Ghaee A. Preparation of aminated chitosan/alginate scaffold containing halloysite nanotubes with improved cell attachment. Carbohydr Polym. 2016;151:1120-31.

27. Kavaklı C, Barsbay M, Tilki S, Güven O, Kavaklı PA. Activation of polyethylene/polypropylene nonwoven fabric by radiation-induced grafting for the removal of $\mathrm{Cr}(\mathrm{VI})$ from aqueous solutions. Water Air Soil Pollut. 2016; 227:473.

28. Bhatt R, Sreedhar B, Padmaja P. Chitosan supramolecularly cross linked with trimesic acid - facile synthesis, characterization and evaluation of adsorption potential for chromium(VI). Int J Biol Macromol. 2017;104: 1254-66.

29. Fan GD, Lin RJ, Su ZY, Lin $X Y, X u R X$, Chen W. Removal of $C r(V I)$ from aqueous solutions by titanate nanomaterials synthesized via hydrothermal method. Can J Chem Eng. 2017;95:717-23.

30. Asthana A, Verma R, Singh AK, Susan MA. Glycine functionalized magnetic nanoparticle entrapped calcium alginate beads: a promising adsorbent for removal of cu(ll) ions. J Environ Chem Eng. 2016:4:1985-95.

31. Kahu SS, Shekhawat A, Saravanan D, Jugade RM. Two fold modified chitosan for enhanced adsorption of hexavalent chromium from simulated wastewater and industrial effluents. Carbohydr Polym. 2016;146:264-73.

32. Yan YZ, An QD, Xiao ZY, Zheng W, Zhai SG. Flexible core-shell/bead-like alginate@PEI with exceptional adsorption capacity, recycling performance toward batch and column sorption of Cr(VI). Chem Eng J. 2017;313:475-86.

33. Igberase E, Osifo P, Ofomaja A. The adsorption of copper (II) ions by polyaniline graft chitosan beads from aqueous solution: equilibrium, kinetic and desorption studies. J Environ Chem Eng. 2014:2:362-9.

34. Ren HX, Gao ZM, Wu DJ, Jiang JH, Sun YM, Luo CW. Efficient Pb(II) removal using sodium alginate-carboxymethyl cellulose gel beads: preparation, characterization, and adsorption mechanism. Carbohydr Polym. 2016;137: 402-9.

35. Houari B, Louhibi S, Tizaoui K, Boukli-hacene L, Benguella B, Roisnel T, et al. New synthetic material removing heavy metals from aqueous solutions and wastewater. Arab J Chem. In press.
36. Doke KM, Khan EM. Equilibrium, kinetic and diffusion mechanism of $\mathrm{Cr}(\mathrm{VI})$ adsorption onto activated carbon derived from wood apple shell. Arab J Chem. 2017;10:\$252-60

37. Ngah WSW, Fatinathan S. Pb(II) biosorption using chitosan and chitosan derivatives beads: equilibrium, ion exchange and mechanism studies. J Environ Sci. 2010;22:338-46.

38. Sharma G, Naushad M, Al-Muhtaseb AH, Kumar A, Khan MR, Kalia S, et al. Fabrication and characterization of chitosan-crosslinked-poly(alginic acid) nanohydrogel for adsorptive removal of $\mathrm{Cr}(\mathrm{VI})$ metal ion from aqueous medium. Int J Biol Macromol. 2017;95:484-93.

39. Karthik $\mathrm{R}$, Meenakshi $\mathrm{S}$. Removal of $\mathrm{Cr}(\mathrm{VI})$ ions by adsorption onto sodium alginate-polyaniline nanofibers. Int J Biol Macromol. 2015;72:711-7.

40. Gedam AH, Dongre RS, Bansiwal AK. Synthesis and characterization of graphite doped chitosan composite for batch adsorption of lead(II) ions from aqueous solution. Adv Mater Lett. 2015;6:59-7.

41. Soltani RDC, Khorramabadi GS, Khataee AR, Jorfi S. Silica nanopowders/ alginate composite for adsorption of lead (II) ions in aqueous solutions. J Taiwan Inst Chem Eng. 2014;45:973-80
Ready to submit your research? Choose BMC and benefit from:

- fast, convenient online submission

- thorough peer review by experienced researchers in your field

- rapid publication on acceptance

- support for research data, including large and complex data types

- gold Open Access which fosters wider collaboration and increased citations

- maximum visibility for your research: over $100 \mathrm{M}$ website views per year

At BMC, research is always in progress.

Learn more biomedcentral.com/submissions 